\title{
Addiction of Internet and Mobile - A Growing Problem
}

\author{
Ms Vandana Sharma, Nashik.
}

\begin{abstract}
Internet is definitely a boon. At the same time Internet addiction among children is also a growing concern. We should utilize technology to compete with this fast world. Every coin has two sides. It's up to us to receive good and to leave bad. Internet addiction, sometimes referred to as cyberspace addiction or online addiction, can manifest itself in many ways in today's teens. The Internet is a seductive place, especially for today's linked-in teens that are far more likely to add graffiti to their friend's Face book wall than they are to actually get on their bicycle and ride over to that same friend's house. We have to admit it would be a challenge to connect face-to-face with someone we've never met in person and who lives in a different time zone. The number of accidents and mishaps has increased to such a $n$ extent that we really need to think that whether gadgets are made for us or we are made for them.
\end{abstract}

Keywords: Challenge, Technology, Graffiti, Manifest, Addiction.

\section{Introduction}

The Internet is perfect for teens. Today's social networking sites like MySpace, Face book, and Twitter let them represent themselves as whomever, or whatever, they want. Everything is edited by them, chosen specifically to present the face they want the world to see. And if they decide to change that face, then they just delete some pictures, add some new friends.

Experts say that as many as 10 percent of Internet users may be considered addicted, although some mental health professionals balk at using that term in a clinical sense. They argue that an activity can only be addictive when it causes a certain type of chemical reaction in the brain, and that's hard to determine.

Many parents feel torn, tough, about limiting their children's time on the computer. If a teen is struggling socially, some parents believe any human interaction, even through the computer, is preferable to none. And with teens that are risk-takers or have questionable taste in friends, some parents feel they can better monitor and keep their children safe by letting them stay home, downloading music files and creating quizzes for their Web pages. And many parents just want to avoid the tantrums, the cold shoulder, or the arguments that flare whenever the issue of computer time management comes up.

There are a couple of Web sites that we and our child can visit together to assess their level of addiction. Try the addiction quizzes at netaddiction.com or mediafamily.org. Even if we don't actually believe our child is addicted, the tests are a good way to initiate some dialogue and get them thinking about how they are spending their time.

\section{Methodology of The Study}

This is a conceptual paper and the researcher has adopted the method of reviewing different research articles, research journals, and case studies, to collect data about internet and mobile usage by youth and its impact on various things, which is consequently incorporated as a concept paper drafted by the researcher.

\section{Problem Areas:}

We have been searching all day. We've traveled hundreds of miles, sometimes backtracking to make sure we haven't missed anything. Some areas are so infested with hostile creatures that we've been prevented from continuing on our journey until the creatures were destroyed. We're so excited that we barely notice how much our back hurts, or do we notice that we are on the verge of getting a migraine or headache.

It may sound like a strange story, but it's all too familiar for video game players ("gamers"). Whether they play on an Xbox or online, they enter worlds filled with witches, elves, dragons, and more, by traveling to mysterious and sometimes secret locations. They spend so much time in this other world, they begin to do physical damage to their bodies.

Physical consequences of internet addiction include carpal tunnel, migraines, sleep disturbances, backaches, eating irregularities, and poor personal hygiene.

\section{Carpal Tunnel Syndrome}

Carpal tunnel syndrome has long been associated with computer use, so it's no surprise that it's a physical symptom of internet addiction. Carpal tunnel syndrome is caused when the main nerve between the forearm and hand is squeezed or pressed. This occurs when the carpal tunnel - the area of the wrist that houses 
the main nerve and tendons - becomes irritated or swollen. Overuse of a computer mouse can cause such irritation and swelling, as can excessive use of a video game controller.

\section{Migraines}

Migraine headaches typically start in one spot and slowly spread, getting more painful as they progress. In severe cases, the pain can be so extreme that it causes the sufferer to vomit. Light and noise can cause excruciating pain. Someone who plays video games for extended periods of time is more prone to migraines because of the intense concentration required and the strain put on the eyes.

\section{Sleep Disturbances:}

The term "sleep disturbances" covers several sleep-related disorders, including insomnia, narcolepsy, sleep apnea, nocturnal myoclonus (periodic leg or arms jerks during sleep), and parasomnia (i.e., night terrors, sleepwalking or talking, and nightmares). Sleep disturbances are caused, in part, by overstimulation of the brain. However, some people can't get a good night's sleep simply because they think obsessively about the game they're playing or internet use.

\section{Backaches}

Backaches are a common physical symptom of internet addiction because most users stay seated in the same position for hours on end. The lack of movement causes stiffness and soreness, but could deteriorate into chronic back problems.

\section{Eating Irregularities}

Eating irregularities are caused by internet addiction simply because most addicted don't want to take the time to eat properly. Rather than eating healthy, balanced meals, they eat food that is quick and usually unhealthy. In extreme cases, the user may choose not to eat at all.

\section{Poor Personal Hygiene:}

An internet addicted is not going to take the time to properly care for himself. Showers, face-washing, and brushing hair and teeth all get put on the back burner. It simply becomes less of a priority, if it's a priority at all.

These physical consequences will occur in varying degrees from one user to another. Though the severity of physical consequences is often tied to the severity of the addiction, this is not always the case. A user that is already in poor physical condition will be more susceptible to these effects early on.

\section{Social Consequences of Internet addiction:}

Our cell phone starts to ring and we look over to see who's calling. It's our best friend. He probably wants to hang out. After all, it is Friday or Saturday night. We think about picking up the phone, but we don't. Instead, we tell ourself, "I'll call him as soon as I finish this fight." We promise our self that I 'll call him because, even though we go to the same school and have most of the same classes, we haven't really hung out in a while. We 've just been too busy. So we promise ourself, but "as soon as I finish. .."

People who are addicted to internet encounter situations like this all the time; situations in which they have to choose whether to interact with the real world or continue living in their virtual one. Sadly, the real world rarely wins.

Social consequences are a very real part of internet addiction. Addicted users spend so much time surfing that their personal relationships get neglected and sometimes disappear altogether. Among internet addicted users who are married, up to 50 percent report a strain in their marriage as a result of their gadget addiction.

A quick search online for information about video game addiction yields multiple stories about detrimental, and potentially harmful, social decisions people have made because gadgets takes priority above all else.

Let's not just neglect that heavy costs that an internet or mobile addicted bear in their relationships. Some of them talk so much about their gadgets of choice - to the exclusion of everything else - that people no longer want to be around them. They can't, or won't, engage in real world conversations or be a source of support or encouragement to friends and family. Because their friends talk about other things, they begin to feel left out, which in turn causes them to feel irritated or offended. It doesn't occur to them that they've chosen to be left out by devoting all their time to internet or mobile.

Some of the physical consequences of internet addiction can lead to social consequences as well. For instance, an addicted user who loses sleep because he's surfing and playing online simply doesn't have the energy to invest in relationships. Lack of sleep may also make him irritable and difficult to be around. 
The lack of social interaction that results from obsessive internet use can have long-term social consequences. An addicted teenager won't develop effective social skills, which will hinder his ability to develop and maintain healthy relationships in college and beyond. Suddenly, he's 21 but has the social skills of a 15 -year-old. He doesn't know how to make friends, talk to girls, or just "hang out" and enjoy people's company.

This type of addiction is a very serious problem. Though there still much debate about whether it is a diagnosable disorder, there is a segment of our society for whom internet use is more than just a casual pastime. These people need friends and family members who care enough to intervene and try to help them break the addictive cycle. It is also observed nowadays that kids also prefer sitting in front of laptops rather than playing in grounds .Physical exercise and games are somewhere lost and the importance of these types of activities need to be discussed with kids and students in colleges.

\section{Why Teens Can't Resist Going Online?}

Internet addiction disorder is a general term used to describe an obsession with the online world in which a user spends an excessive amount of time engaged in computer-related activities. These activities may include web surfing, social networking (Face book), online shopping, Internet pornography, and video games.

\section{Too Much Time Online}

No age group is immune to online addictions. Children, teens, and even adults can develop internet addictions. For teenagers, Internet addiction may be especially problematic. After all, today's teens have literally grown up with the Internet and what may be considered "too much time online" by adults may seem quite normal to many teens.

Still, just because something seems normal to a teen does not mean that it is healthy, and parents need to be aware of the dangers of teenage Internet addiction.

\section{Internet Addiction in Teenagers - The Signs Your Teen May Have a Problem}

1. Spending an excessive number of hours online each day.

2. Going online at every opportunity.

3. Falling school grades and little attention given to homework

4. Ignoring family and friends in favor of Internet use

5. Claiming that his or her only real friends are online

6. Becoming angry at parents when Internet time is limited

7. Staying up very late to be online

8. Lying about online activities

9. A strong preference for using the Internet over all other activities

\section{The Internet - Custom Designed for Teenagers}

Think about teenagers' natural developmental needs and interests - exploration, sensation seeking, obtaining new information about the world around them, feeling understood, testing limits, connecting with friends, discovering who they are and what is important to them, etc.

\section{Now think about what the Internet offers:}

Information on anything, an easy way to find others "just like me", excitement, support, an element of danger that can be explored in relative safety, social connections, entertainment.Almost everything the teenagers are looking for is conveniently packaged in an easily accessible digital form. Regardless of whether they are at home using a computer or away from home using a Smartphone, the Internet is never more than a click away. If they choose, they can be constantly connected.

The Internet is a part and parcel of our lives. It is very easy to understand that the immediate access to information we now have, has been a positive development for billions of people worldwide.

However, as is true for almost any enjoyable activity (eating, exercise, TV, drinking, gambling, sex), there are some people (teenagers included) who become addicted to the Internet or obsessed with computer games. Current estimates of Internet addiction are quite variable, but most published studies estimate that between 5 and 10 percent of Internet users may be addicted. Of course, Internet addiction is not an official diagnosis but the term used to describe the condition is really not as important as recognizing that from some teens, excessive Internet use is a real problem that detracts from the quality of their lives in the real world. Recognizing this, a few psychologists are now offering online help and downloadable workbooks for Internet and video game addiction. 


\section{Parents Playing a tough Role:}

Even though they worry that their teen is spending too much time online, many parents struggle to set limits on screen time. Parents can see how much their child enjoys his/her online interest and they are reluctant to take this away. Parents may hope that excessive Internet use is a passing phase that will go away naturally when the teen develops other interests.

Some parents reason that they would rather have their teens in the safety of their own homes than outside the home where they cannot monitor who they are with and what they are doing (even if their only real activity at home is being online).

Although it is not a very good long-term strategy, parents may allow excessive Internet use to avoid the arguments and fights that may come from trying to set limits.

For shy or socially anxious teenagers with few friends, parents may simply be happy that their teen is interacting socially with others - even if it only happens online. As such, they may be reluctant to take away this one social outlet.

\section{Advice for Parents:}

Parents who are struggling with teenage Internet addiction need to keep in mind that Internet use is a privilege not a right. Even though all their friends can go online "whenever they want" this does not mean that unrestricted Internet access is a right for your child. It is perfectly reasonable to expect that homework, chores, and other responsibilities are completed (and completed properly) before a teen is allowed to go online. If new limits are set (for example, 90 minutes of recreational Internet use or gaming per night), it is critical that these rules are consistently enforced and that there are predictable consequences for not following the rules. Teenage Internet addiction and video game addiction can be beaten but it may often require "tough love" from parents.

With kids ages 8 to 18 spending on average 44.5 hours per week in front of screens, parent are increasingly concerned that screen time is robbing them of real world experiences. Nearly $23 \%$ of youth report that they feel "addicted to video games" (31\% of males, $13 \%$ of females.) These are the results of a new study of 1,178 U.S. children and teens (ages 8 to 18) conducted by Harris Interactive (2007) that documents a national prevalence rate of pathological video game use.

Dr. Douglas Gentile, Director of the Media Research Lab at Iowa State University reports, "Almost one out of every ten youth gamers shows enough symptoms of damage to their school, family, and psychological functioning to merit serious concern."

Beyond gaming, kids are filling their free time with other Internet activities: social networking, instant messaging (IM), blogging, downloading etc.

Dr. Kimberly Young, Director of the Center for Internet Addiction Recovery, identified the following potential warning signs for children with pathological Internet use:

- $\quad$ Loses track of time while online

- Sacrifices needed hours of sleep to spend time online

- Becomes agitated or angry when online time is interrupted

- Checks email several times a day

- Becomes irritable if not allowed access to the Internet

- Spends time online in place of homework or chores

- Prefers to spend time online rather than with friends or family

- Disobeys time limits that have been set for internet usage

- Lies about amount of time spent online or "sneaks" online when no one is around

- Forms new relationships with people he or she has met online

- Seems preoccupied with getting back online when away from the computer

- Loses interest in activities that were enjoyable before he or she had online access

- Becomes irritable, moody or depressed when not online

\section{Emotional Perspective}

Online access is a vital part of the modern world and an important tool in the education of our children. In addition, it is a highly entertaining and informative medium. However, these very qualities also make it an enticing escape for many children. They can be anyone in an online chat room, or play thrilling and challenging games against other players from all corners of the globe. With the click of a mouse, they can enter a different world where the problems of their real life are no longer present, and all the things one wishes he or she could be or experience are possible.

Like addiction to drugs and alcohol, the Internet offers children and adolescents a way to escape painful feelings or troubling situations. They sacrifice needed hours of sleep to spend time online and withdraw from family and friends to escape into a comfortable online world that they have created and shaped. 
Children who lack rewarding or nurturing relationships or who suffer from poor social and coping skills are at greater risk to developing inappropriate or excessive online habits. Because they feel alone, alienated, and have problems making new friends, they turn to invisible strangers in online chat rooms looking for the attention and companionship missing in their real lives. They may come from families with significant problems, and they cope with their problems by spending time online.

Socially, they learn to instant message friends rather than develop face-to-face relationships, which can impact their way of relating to peers.

\section{As one principal explained:}

The internet is hurting their ability to work in groups. Our teachers struggle to get them to participate in any kind of team assignments; instead they would all rather stare at the computer. When I observe them talking to one another in the hallway, I see young girls who are socially aggressive or inappropriate, and I can't help but think that the Internet is socializing them in ways that emotionally stunts them and makes it difficult for them to deal with others in the real world.

\section{How to address the problem?}

In a two-parent household, it is critical that both parents present a united front. As parents, each must take the issue seriously and agree on common goals. Discuss the situation together and if necessary, compromise on desired goals so that when we approach our child, we will be coming from the same perspective. If we do not, our child will appeal to the more skeptical parent and create division between us.

In a single-parent household, the parent needs to take some time to think about what needs to be said and to prepare for the likely emotional response from the child. A child who is addicted to the Internet or becoming addicted to it will feel threatened at the very idea of curbing computer time. A single parent needs to be prepared for an emotional outburst laden with accusatory phrases designed to make the parent feel guilty or inadequate. It is important not to respond to the emotion-or worse yet, get sidetracked with a lecture on disrespect. Acknowledge your child's feelings but stay focused on the topic of his or her Internet use.

Internet addiction disorder, sometimes abbreviated as IAD, is also known by other names, such as Internet over use, pathological computer use, and problematic computer use.

Dr. Ivan Goldberg originally proposed IAD as a psychiatric disorder in 1995 based on the description of compulsive gambling. The Diagnostic and Statistical Manual of Mental Disorders V doesn't recognize Internet addiction as a disorder, but it does list it as a condition for further study.

\section{Understanding Internet Addictions:}

The concept of Internet addiction has become more widely accepted since 2000, primarily due to the fact that it's becoming increasingly difficult for some to distinguish between online and offline life. Experts in addiction medicine take varying stances in classifying Internet addiction as a psychiatric disorder.

\section{Steps we can take to help someone with a Computer or Internet Addiction}

- Introduce the Internet addict to other people who handle their use of the Internet reasonably.

- Serve as a good role model for the Internet addict by properly managing your own use of computers and the Internet.

- Support a person's desire for change if it appears that he or she is an Internet addict.

- Talk to the person about your concerns that he or she may be an Internet addict.

- Get the person involved in interests that aren't related to the Internet.

- Encourage an Internet addict to seek professional counseling.

\section{Show you Care:}

It will help to begin our discussion by reminding our child that we love him or her and that we care about his or her happiness and well-being. Children often interpret questions about their behavior as blame and criticism. We need to reassure our child that we are not condemning him or her. Rather, tell our child we are concerned about some of the changes we have seen in his or her behavior and refer to those changes in specific terms: fatigue, declining grades, giving up hobbies, social withdrawal, etc. Assign an Internet time log- Telling our child that we would like to see an accounting of just how much time he or she spends online each day and which internet activities they engage in.

Remind them that with television we can monitor their viewing habits more easily, but with the Internet we need their help and cooperation to become appropriately involved. Put them on the honor system to keep the $\log$ themselves for a week or two to build trust between us. If they balk at this idea or clearly lie in their log, you are likely dealing with their denial of addiction. 


\section{Become more computer-savvy:}

Checking history folders and Internet logs, learning about monitoring software, and installing filters all require a degree of computer savvy. It is important for every parent to learn the terms (both technical and popular) and be comfortable with the computer, at least enough to know what your child is doing online. Take an active interest in the Internet and learn about where your child goes online.

\section{Set reasonable rules:}

Many parents get angry when they see the signs of Internet addiction in their child and take the computer away as a form of punishment. Others become frightened and force their child to quit cold turkey, believing that is the only way to get rid of the problem. Both approaches invite trouble- our child will internalize the message that they are bad; they will look at us as the enemy instead of an ally; and they will suffer real withdrawal symptoms of nervousness, anger, and irritability. Instead, work with our children to establish clear boundaries for limited Internet usage. Allow perhaps an hour per night after homework, with a few extra weekend hours. Stick to some rules .Remember that we're not simply trying to control him or her instead we are working to free them of a psychological dependence.

\section{Conclusion}

With relevant education, work experience, improving economic conditions and financial References we can now easily share the resources available to us in this modern era. We should also not forget that the coming generations are prone to internet addictions along with other types. We all need to work together to set free our children from this type of disorder and make them realize that they are blessed with a beautiful life to enjoy each moment as it is presented in front of them by god. They should use the internet with a limit that's it.

\section{References}

[1]. Weinstein A, Lejoyeux M. Internet addiction or excessive Internet use. The American Journal of Drug and Alcohol Abuse. 2010 Aug;36(5 ):277-83. [PubMed]

[2]. Beard KW. Internet addiction: a review of current assessment techniques and potential assessment questions. CyberPsychology \& Behavior. 2005 Feb;8(1 ):7-14. [PubMed]

[3]. Chou C, Condron L, Belland JC. A review of the research on Internet addiction. Educational Psychology Review. 2005 Dec;17(4 ):363-88.

[4]. Douglas AC, Mills JE, Niang M, Stepchenkova S, Byun S, Ruffini C, et al. Internet addiction: meta-synthesis of qualitative research for the decade 1996-2006. Computers in Human Behavior. 2008 Sep;24(6 ):3027-44.

[5]. Wolfling K, Buhler M, Lemenager T, Morsen C, Mann K. Gambling and internet addiction. Review and research agenda. Der Nervenarzt. 2009 Sep;80(9):1030-9. [PubMed]

[6]. Petersen KU, Weymann N, Schelb Y, Thiel R, Thomasius R. Pathological Internet use - epidemiology, diagnostics, co-occurring disorders and treatment. Fortschritte Der Neurologie Psychiatrie. [Review] 2009 May;77(5 ):263-71. [PubMed]

[7]. Peukert P, Sieslack S, Barth G, Batra A. Internet- and computer game addiction: Phenomenology, comorbidity, etiology, diagnostics and therapeutic implications for the addictives and their relatives.Psychiatrische Praxis. 2010 Jul;37(5 ):21924. [PubMed]

[8]. Widyanto L, Griffiths MD. 'Internet addiction': a critical review. International Journal of Mental Health and Addiction. 2006 Jan;4(1 ):31-51.

[9]. American Psychiatric Association. Diagnostic and statistical manual of mental disorders. (4th ed., text rev.) Washington, DC: 2000. Author.

[10]. Young KS. Internet addiction: The emergence of a new clinical disorder. 104th annual meeting of the American Psychological Association; August 11 1996; Toronto, Canada.

[11]. American Psychiatric Association. DSM-5 Publication Date Moved to May 2013. 2009 [cited 2011 August 21]; [Press release]. Available from: http: //www.psych.org/MainMenu/Newsroom/ NewsReleases/2009NewsReleases/DSM-5-Publication-DateMoved-.aspx .

[12]. Block JJ. Issues for DSM-V: Internet addiction. The American Journal of Psychiatry. 2008 Mar;165(3 ):3067. [Editorial] [PubMed]

[13]. Pies R. Should DSM-V designate "Internet addiction" a mental disorder? Psychiatry. 2009 Feb;6(2 ):31-7. [PMC free article] [PubMed]

[14]. O'Brien CP. Commentary on Tao et al. (2010): Internet addiction and DSM-V. Addiction. [Comment/Reply] 2010 Mar;105(3 ):565.

[15]. Czincz J, Hechanova R. Internet addiction: Debating the diagnosis. Journal of Technology in Human Services. 2009 Oct;27(4 )$: 257-72$.

[16]. Young KS. Caught in the net: how to recognize the signs of Internet addiction and a winning strategy for recovery. New York: J. Wiley; 1998.

[17]. Young KS. Internet addiction: the emergence of a new clinical disorder. CyberPsychology \& Behavior.1998 Fal ;1(3 ):237-44.

[18]. Kratzer S, Hegerl U. Is "Internet Addiction" a disorder of its own? A study on subjects with excessive internet use. Psychiatrische Praxis. 2008 Mar;35(2 ):80-3. [PubMed]

[19]. Grant JE, Potenza MN, Weinstein A, Gorelick DA. Introduction to behavioral addictions. The American Journal of Drug and Alcohol Abuse. 2010 Aug;36(5 ):233-41. [PMC free article] [PubMed]

[20]. American Society of Addiction Medicine. Public Policy Statement: Definition of Addiction. 2011 [cited 2011 August 21]; http: //www.asam.org/1DEFINITION_OF_ADDICTION_LONG_4-11.pdf. Public Policy Statement: Definition of Addiction. 2011 [cited 2011 Augus.

[21]. Davis RA. A cognitive behavioral model of pathological internet use (PIU) Computers in Human Behavior. 2001;17(2 ):187-95.

[22]. Dowling NA, Quirk KL. Screening for Internet dependence: Do the proposed diagnostic criteria differentiate normal from dependent Internet use? CyberPsychology \& Behavior. 2009 Feb;12(1 ):21-7.[PubMed] 
[23]. Caplan SE. Problematic Internet use and psychosocial well-being: development of a theory-based cognitive-behavioral measurement instrument. Computers in Human Behavior. 2002;18(5 ):553-75.

[24]. Winkler A, Dörsing B. Treatment of internet addiction disorder: a first meta-analysis [Diploma thesis]Marburg: University of Marburg; 2011.

[25]. Byun S, Ruffini C, Mills JE, Douglas AC, Niang M, Stepchenkova S, et al. Internet addiction: metasynthesis of $1996-2006$ quantitative research. CyberPsychology \& Behavior. 2009 Apr;12(2 ):203-7.[PubMed]

[26]. Demetrovics Z, Szeredi B, Rozsa S. The three-factor model of Internet addiction: the development of the Problematic Internet Use Questionnaire. Behavior Research Methods. 2008;40(2 ):563-74. [PubMed]

[27]. Meerkerk G, Van Den Eijnden R, Vermulst A, Garretsen H. The Compulsive Internet Use Scale (CIUS): some psychometric properties. CyberPsychology \& Behavior. 2009 Feb;12(1):1-6. [PubMed]

[28]. Chakraborty K, Basu D, Kumar K. Internet addiction: Consensus, controversies, and the way ahead.East Asian Archives of Psychiatry. 2010 Sep;20(3 ):123-32. [PubMed]

[29]. Young KS, Nabuco de Abreu C. Internet Addiction: A handbook and guide to evaluation and treatment. New Jersey: John Wiley \& Sons Inc; 2011.

[30]. Young KS, Griffin-Shelley E, Cooper A, O'Mara J, Buchanan J. Online infidelity: A new dimension in couple relationships with implications for evaluation and treatment. Sexual Addiction \& Compulsivity.2000;7(1-2 ):59-74.

[31]. Cooper A, Putnam DE, Planchon LA, Boies SC. Online sexual compulsivity: getting tangled in the net.Sexual Addiction \& Compulsivity. 1999;6(2 ):79-104.

[32]. Grohol JM. Internet addiction guide. Internet addiction guide. 1999 [updated 2005, April 16; cited 2011 April 20]; Available from: http: //psychcentral.com/ netaddiction/

[33]. Linden DJ. The Compass of Pleasure: How Our Brains Make Fatty Foods, Orgasm, Exercise, Marijuana, Generosity, Vodka, Learning, and Gambling Feel So Good. Viking Adult. 2011.

[34]. Gabor Maté MD. In the Realm of Hungry Ghosts: Close Encounters with Addiction. North Atlantic Books. 2010.

[35]. Bai Y-M, Lin C-C, Chen J-Y. Internet Addiction Disorder Among Clients of a Virtual Clinic. Psychiatric Services. 2001;52(10 ):1397. [Letter] [PubMed]

[36]. Ko C-H, Liu G-C, Hsiao S, Yen J-Y, Yang M-J, Lin W-C, et al. Brain activities associated with gaming urge of online gaming addiction. Journal of Psychiatric Research. 2009;43(7 ):739-47. [PubMed]

[37]. Amichai-Hamburger Y, Ben-Artzi E. Loneliness and Internet use. Computers in Human Behavior.2003;19(1):71-80.

[38]. Eisen S, Lin N, Lyons M, Scherrer J, Griffith K, True W, et al. Familial influences on gambling behavior: an analysis of 3359 twin pairs. Addiction. 1998 Sep;1998:1375-84. [PubMed]

[39]. Grant JE, Brewer JA, Potenza MN. The neurobiology of substance and behavioral addictions. CNS Spectrums. 2006. 2006 Dec;11(12):924-30. [PubMed]

[40]. Dong G, Lu Q, Zhou H, Zhao X. Precursor or sequela: pathological disorders in people with Internet addiction disorder. Public Library of Science One [serial on the Internet] 2011;6(2 ) Available from: http: //www.plosone.org/article/info\%3Adoi\%2F10.1371\%2Fjournal. pone.0014703 . [PMC free article][PubMed]

[41]. Young KS. Internet Addiction: Symptoms, Evaluation, And Treatment. Innovations in Clinical Practice [serial on the Internet]. 1999;17 Available from: http: //treatmentcenters.com/downloads/ internet-addiction.pdf .

[42]. Arisoy O. Internet addiction and its treatment. Psikiyatride Guncel Yaklasimlar. 2009;1(1 ):55-67.

[43]. Atmaca M. A case of problematic Internet use successfully treated with an SSRI-antipsychotic combination. Progress in NeuroPsychopharmacology \& Biological Psychiatry. 2007 May;31(4 ):961-2.[Letter] [PubMed]

[44]. Huang X-q, Li M-c, Tao R. Treatment of Internet addiction. Current Psychiatry Reports. 2010 Oct ;12(5):462-70. [PubMed]

[45]. Sattar P, Ramaswamy S. Internet gaming addiction. Canadian Journal of Psychiatry. 2004 Dec;49(12 ):871-2.

[46]. Wieland DM. Computer addiction: implications for nursing psychotherapy practice. Perspectives in Psychiatric Care. 2005 OctDec;41(4 ):153-61. [PubMed]

[47]. Dell'Osso B, Hadley S, Allen A, Baker B, Chaplin WF, Hollander E. Escitalopram in the treatment of impulsive-compulsive Internet usage disorder: an open-label trial followed by a double-blind discontinuation phase. Journal of Clinical Psychiatry. 2008 Mar;69(3 ):452-6. [PubMed]

[48]. Han DH, Hwang JW, Renshaw PF. Bupropion sustained release treatment decreases craving for video games and cue-induced brain activity in patients with Internet video game addiction. Experimental and Clinical Psychopharmacology. 2010 Aug;18(4 ):297304. [PubMed]

[49]. Han DH, Lee YS, Na C, Ahn JY, Chung US, Daniels MA, et al. The effect of methylphenidate on Internet video game play in children with attention-deficit/hyperactivity disorder. Comprehensive Psychiatry.2009 May-Jun;50(3 ):251-6. [PubMed]

[50]. Shapira NA, Goldsmith TD, Keck PE, Jr, Khosla UM, McElroy SL. Psychiatric features of individuals with problematic Internet use. Journal of affective disorders. 2000 Jan-Mar;57(1-3 ):267-72. [PubMed]

[51]. Bostwick JM, Bucci JA. Internet sex addiction treated with naltrexone. Mayo Clinic Proceedings.2008;83(2 ):226-30. [PubMed]

[52]. Greenfield DN. Suchtfalle Internet. Hilfe fuer Cyberfreaks, Netheads und ihre Partner. Virtual addiction: Zuerich: Walter. 2000.

[53]. Lanjun Z. The applications of group mental therapy and sports exercise prescriptions in the intervention of Internet addiction disorder. Psychological Science (China) 2009 May;32(3 ):738-41.

[54]. Miller WR, Rollnick S. In: Motivational interviewing: preparing people for change. 2nd ed. Miller WR, Rollnick S, editors. New York: Guilford Press; 2002.

[55]. Miller NH. Motivational interviewing as a prelude to coaching in healthcare settings. Journal of Cardiovascular Nursing. 2010 MayJun;25(3 ):247-51. [PubMed]

[56]. Burke BL, Arkowitz H, Menchola M. The efficacy of motivational interviewing: a meta-analysis of controlled clinical trials. Journal of consulting and clinical psychology. 2003 Oct;71(5 ):843-61. [PubMed]

[57]. Meyers RJ, Miller WR, Smith JE. Community reinforcement and family training (CRAFT) In: Meyers RJ, Miller WR, editors. A community reinforcement approach to addiction treatment. New York, NY: Cambridge University Press; US; 2001. pp. 147-60.

[58]. Kim J-U. A reality therapy group counseling program as an Internet addiction recovery method for college students in Korea. International Journal of Reality Therapy. 2007 Spr ;26(2 ):3-9.

[59]. Kim J-U. The effect of a R/T group counseling program on the Internet addiction level and self-esteem of Internet addiction university students. International Journal of Reality Therapy. 2008 Spr; 27(2 ):4-12.

[60]. Twohig MP, Crosby JM. Acceptance and Commitment Therapy as a treatment for problematic Internet pornography viewing. Behavior Therapy. 2010 Sep;41(3 ):285-95. [PubMed]

[61]. Abreu CN, Goes DS. Psychotherapy for Internet addiction. In: Young KS, de Abreu CN, editors. Internet addiction: A handbook and guide to evaluation and treatment. Hoboken, NJ: John Wiley \& Sons Inc; US; 2011. pp. 155-71. 
[62]. Young KS. Cognitive behavior therapy with Internet addicts: treatment outcomes and implications.CyberPsychology \& Behavior. 2007 Oct;10(5 ):671-9. [PubMed]

[63]. Cao F-L, Su L-Y, Gao X-P. Control study of group psychotherapy on middle school students with Internet overuse. Chinese Mental Health Journal. 2007 May;21(5 ):346-9.

[64]. Li G, Dai X-Y. Control study of cognitive-behavior therapy in adolescents with Internet addiction disorder. Chinese Mental Health Journal. 2009 Jul;23(7 ):457-70.

[65]. Zhu T-m, Jin R-j, Zhong X-m. Clinical effect of electroacupuncture combined with psychologic interference on patient with Internet addiction disorder. Chinese Journal of Integrated Traditional \& Western Medicine. 2009 Mar;29(3 ):212-4. [PubMed]

[66]. Orzack MH, Orzack DS. Treatment of computer addicts with complex co-morbid psychiatric disorders.Cyberpsychology \& Behavior. 1999;2(5):465-73. [PubMed]

[67]. Du Y-s, Jiang W, Vance A. Longer term effect of randomized, controlled group cognitive behavioural therapy for Internet addiction in adolescent students in Shanghai. Australian and New Zealand Journal of Psychiatry. 2010;44(2 ):129-34. [PubMed]

[68]. Fang-ru Y, Wei H. The effect of integrated psychosocial intervention on 52 adolescents with Internet addiction disorder. Chinese Journal of Clinical Psychology. 2005 Aug;13(3 ):343-5.

[69]. Orzack MH, Voluse AC, Wolf D, Hennen J. An ongoing study of group treatment for men involved in problematic Internet-enabled sexual behavior. CyberPsychology \& Behavior. 2006 Jun;9(3 ):348-60.[PubMed]

[70]. Rong Y, Zhi S, Yong Z. Comprehensive intervention on Internet addiction of middle school students.Chinese Mental Health Journal. 2006 Jul;19(7 ):457-9.

[71]. Shek DTL, Tang VMY, Lo CY. Evaluation of an Internet addiction treatment program for Chinese adolescents in Hong Kong. Adolescence. 2009;44(174 ):359-73. [PubMed]

[72]. Bai Y, Fan FM. The effects of group counseling on Internet-dependent college students. Chinese Mental Health Journal. 2007;21(4 )$: 247-50$. 